\title{
KEEFEKTIFAN TEKNIK BRAINSTORMING DALAM KETERAMPILAN MENULIS KARANGAN BAHASA JERMAN SISWA KELAS XI IPA SMA NEGERI 1 SUNGGUMINASA
}

\author{
Arlian Fachrul Syaputra ${ }^{1}$ dan Mantasiah $^{2}$ \\ Fakultas Bahasa dan Sastra, Universitas Negeri Makassar \\ Email ${ }^{1}:$ arlianfachrul5@gmail.com
}

\begin{abstract}
ABSTRAK
Penelitian ini dilakukan untuk memerolehnformasi tentang keefektifan teknik Brainstorming dalam keterampilan menulis karangan bahasa Jerman. Jenis penelitian ini adalah Quasieksperimen. Populasi penelitian ini adalah siswa kelas XI IPA SMA Negeri 1 Sungguminasa Kabupaten Gowa yang terdiri dari 9 kelas yang berjumlah 315 siswa. Sampel dalam penelitian ini random sampling yakni XI IPA 2 yang berjumlah 35 siswa sebagai kelas eksperimen dan siswa kelas XI IPA 1 yang berjumlah 35 siswa. Pengumpulan data melalui tes keterampilan menulis karangan. Data dianalasis menggunakan analisis Uji-t. Hasil analisis data menunjukkan bahwa $t_{h} 5,81>t_{t} 1,998$. Hasil penelitian menunjukkan bahwa teknik Brainstorming efektf dalam keterampilan menulis karangan bahasa Jerman siswa kelas XI IPA SMA Negeri 1 Sungguminasa Kabupaten Gowa.
\end{abstract}

\section{Kata Kunci : Efektivitas, Teknik Brainstorming, dan Keterampilan Menulis}

\begin{abstract}
The purpose of this study was to know the effectiveness of brainstorming technique in writing a german language essay. This study was quasy-experiment approach. Population of this study was students of XI IPA SMA Negeri 1 Sungguminasa, Gowa district which consisted of 9 classes which had 315 students. Research sampel amounted 35 students chosen randomly . Data collection technique consisted of writing test. Data analysis technique used ttest. The result of study showed that $t_{h} 5,81>t_{t} 1,998$. It means that brainstorming technique was effective to be used in writing a german language essay.
\end{abstract}

Keywords: Effectiveness, Brainstorming Technique,and Writing Skill.

\section{PENDAHULUAN}

Bahasa merupakan alat utama dalam mendukung segala aktivitas manusia. Penggunaan bahasa sebagai alat komunikasi sehari-hari merupakan salah satu wujud hakikat manusia sebagai makhluk sosial yang selalu berinteraksi dengan manusia lain. Manusia dapat menyampaikan dan bertukar pengetahuan serta informasi dengan sesama menggunakan bahasa. Selain itu, bahasa besar perannya dalam proses berpikir, karena segala macam bentuk ide dan gagasan diungkapkan dengan bahasa. Agar proses berkomunikasi dapat berlangsung dengan baik diperlukan keterampilan berbahasa yang baik pula (Nurmiati, 2017). 
Salah satu bahasa asing yang dipelajari di SMA/MA adalah bahasa Jerman dan menulis merupakan salah satu aspek yang berperan penting dalam pengajaran bahasa Jerman, dengan menulis seseorang dapat mengungkapkan ide, pikiran, gagasan kepada orang lain secara tertulis.

Pembelajaran bahasa Jerman di sekolah seharusnya berjalan dengan baik sesuai dengan standar kompetensi pembelajaran bahasa Jerman dalam keterampilan menulis yaitu kemampuan siswa untuk menulis kata,frasa, dan kalimat dengan huruf, ejaan dan tanda baca yang tepat serta mampu mengungkapkan informasi secara tertulis dalam bentuk paparan ,dialog, atau wacana sederhana terkait tema yang sedang dipelajari.

Pada pembelajaran bahasa Jerman di sekolah masih banyak ditemukan kendala. Beberapa siswa belum mampu menyampaikan gagasan, ide, pikiran secara tertulis. Berdasarkan hasil observasi penulis melalui wawancara pengajar bahasa Jerman dan beberapa siswa pada tanggal 19 Januari 2017 di SMA Negeri 1 Sungguminasa Kabupaten Gowa diperoleh informasi bahwa beberapa siswa mengalami kesulitan dalam keterampilan menulis hal tersebut dapat dilihat dari lembar kerja dan data nilai keterampilan menulis siswa SMA Negeri 1 Sungguminasa Kabupaten Gowa yang ratarata mendapatkan nilai di bawah standar Kriteria Ketuntasan Minimal (KKM) yaitu 70. Hal ini disebabkan karena beberapa siswa kurang memahami bahasa Jerman sehingga menimbulkan rasa malas, rasa tidak peduli terhadap pelajaran bahasa Jerman.

Kesulitan tersebut dapat diatasi dengan menggunakan teknik pembelajaran yang inovatif dan kreatif. Ada berbagai macam teknik pembelajaran yang dapat digunakan sesuai dengan tujuan pembelajaran Salah satu teknik pembelajaran yang dapat digunakan dalam pembelajaran keterampilan menulis karangan bahasa Jerman adalah teknik Brainstorming. Teknik Brainstorming merupakan salah satu teknik yang bertujuan untuk membantu siswa menyalurkan ide-ide mereka tanpa rasa takut akan kesalahan. Selain itu, melalui teknik ini diharapkan siswa akan lebih aktif dalam proses pembelajaran sehingga ide yang mereka cetuskan dapat tersalurkan secara optimal serta tercapainya tujuan pembelajaran yang telah dirumuskan sebelumnya.

\section{TEKNIK BRAINSTORMING}

Teknik Brainstorming adalah suatu teknik mengajar yang melibatkan siswa dengan cara melontarkan masalah siswa dan mengajak siswa ke masalah tersebut sehingga siswa melibatkan daya pikir, ide, gagasan bahkan tanggapan mereka. Pendapat pertama mengenai teknik Brainstorming dikemukakan oleh Iskandarwassid dan Dadang (2009:69) bahwa teknik Brainstorming atau yang dikenal dalam bahasa Indonesia sebagai teknik sumbang saran atau curah pendapat merupakan teknik pembelajaran yang cara penyajiannya yaitu dengan pelontaran masalah kepada siswa yang harus dijawab atau ditanggapi oleh mereka sehingga masalah tersebut berkembang menjadi masalah baru.

Selanjutnya teknik Brainstorming yang dikemukakan oleh Suprijanto (2009:122) adalah salah satu bentuk berpikir kreatif sehingga pertimbangan memberikan jalan untuk berinisiatif kreatif. Peserta akan dimotivasi untuk mencurahkan semua ide 
yang timbul dari pikirannya dalam jangka waktu tertentu berkenaan dengan beberapa masalah dan tidak diminta untuk diberikan penilaian selama curah pendapatnya berlangsung. Pendapat lain tentang pengertian Brainstorming juga dikemukakan oleh Sudiyono dkk (2006:120) bahwa Brainstorming adalah sebuah teknik yang digunakan dalam suatu pembelajaran untuk membantu siswa memikirkan sebanyak mungkin ide dan gagasan. Selama berlangsungnya curah pendapat, siswa didorong untuk menghasilkan pendapat atau gagasan secepat mungkin tanpa perlu memikirkan nilai dari pendapatnya itu.

Lebih lanjut Roestiyah (2008:74) berpendapat bahwa Brainstorming adalah suatu teknik atau cara mengajar yang dilaksanakan oleh guru di dalam kelas dengan cara melontarkan masalah ke kelas, kemudian peserta didik menjawab atau menyatakan pendapat atau komentar sehingga mungkin berkembang menjadi masalah baru atau dapat diartikan sebagai salah satu cara untuk mendapatkan ide dari sekelompok manusia dalam waktu singkat.

Berikut beberapa kelebihan dan kekurangan dari teknik Brainstorming yang dikemukan oleh beberapa ahli. Menurut Roestiyah (2008:74) Brainstorming digunakan karena memiliki banyak keunggulan seperti:

1. anak-anak aktif berpikir untuk menyatakan pendapat;

2. melatih siswa berpikir dengan cepat dan tersusun logis;

3. merangsang siswa untuk selalu siap berpendapat yang berhubungan dengan masalah yang diberikan oleh guru;

4. meningkatkan parisipasi siswa dalam menerima pelajaran;
5. siswa yang kurang aktif mendapat bantuan dari temannya atau dari guru;

6. terjadi persaingan yang sehat;

7. anak merasa bebas dan gembira;

8. suasana demokrasi dan disiplin dapat ditumbuhkan.

Namun Brainstorming juga memiliki kekurangan, seperti yang dikemukakan Roestiyah (2008:75) yaitu:

1. guru kurang memberi waktu yang cukup kepada siswa untuk berfikir dengan baik;

2. anak yang kurang, selalu ketinggalan;

3. guru hanya menampung pendapat tidak pernah merumuskan kesimpulan;

4. siswa tidak segera tahu apakah pendapatnya itu betul atau salah;

5. tidak menjamin hasil pemecahan masalah;

6. masalah bisa berkembang ke arah yang tidak diharapkan.

Teknik Brainstorming memerlukan langkah-langkah dalam penerapannya di dalam proses pembelajaran. Adapun langkah-langkah penerapan teknik Brainstorming yang dijabarkan oleh Suprayekti (Dalam Meisin 2015:39) sebagai berikut: 1 . persiapan; 2 . pelaksanaan; 3. umpan balik. Adapun menurut Roestiyah (2008:74-75) langkahlangkah pembelajaran Brainstorming yaitu: 1. pemberian informasi dan motivasi; 2 . identifikasi; 3. klarifikasi; 4. verifikasi.

\section{METODE PENELITIAN}

Penelitian ini merupakan penelitian eksperimen. Penelitian ini menggunakan dua variabel yaitu teknik Brainstorming sebagai veriabel bebas (X) dan keterampilan menulis karangan bahasa Jerman siswa kelas XI IPA SMA Negeri 1 Sungguminasa Kabupaten Gowa sebagai 
variabel terikat (Y). Desain penelitan yang digunakan adalah penelitian eksperimen semu (quasi experimental design) non equivalent control grup).

Penelitian ini terdiri atas dua kelompok yaitu kelas eksperimen dan kelas kontrol. Kelas eksperimen diberi perlakuan atau treatment dengan menggunakan teknik Brainstorming sedangkan pada kelas kontrol tanpa menggunakan teknik

\section{Brainstorming.}

Variabel yang digunakan dalam penelitian ini yaitu penggunaan teknik Brainstorming sebagai variabel bebas (X) dan keterampilan menulis karangan bahasa Jerman siswa kelas XI IPA SMA Negeri 1 Sungguminasa Kabupaten Gowa sebagai variabel terikat (Y). Teknik Brainstorming yang dimaksud dalam penelitian ini adalah suatu cara penyajian bahan pelajaran secara berkelompok dengan konsep curah pendapat mengenai masalah atau tema yang diberikan kepada siswa sehingga beberapa pendapat yang dikemukakan oleh siswa dapat menjadi sebuah karangan bahasa Jerman.

Keterampilan menulis karangan bahasa Jerman yang dimaksud dalam penelitian ini adalah kemampuan siswa dalam menulis karangan bahasa Jerman dengan tema die Familie.

Populasi dalam penelitian ini adalah seluruh siswa kelas XI IPA SMA Negeri 1 Sungguminasa Kabupaten Gowa yang berjumlah 9 kelas dengan jumlah keseluruhan siswa adalah 315 siswa. Dari populasi yang ada terpilih kelas XI IPA 2 yang berjumlah 35 siswa sebagai kelas eksperimen dan XI IPA 1 yang berjumlah 35 siswa sebagai kelas kontrol sehingga total sampel berjumlah 70 siswa. Teknik yang digunakan dalam pengambilan sampel penelitian ini adalah random sampling.

Prosedur pengumpulan data pada penelitian ini adalah sebagai berikut:

\section{Tes awal (pretest)}

Pada tahap ini peneliti memberikan test awal (pretest) kepada kedua kelompok kelas yaitu kelas eksperimen dan kelas kontrol untuk mengukur kemampuan awal siswa mengenai keterampilan menulis karangan bahasa Jerman sebelum diberikan perlakuan (treatment).

\section{Tes akhir (posttest)}

Setelah diberikan perlakuan (treatment) berupa penggunaan teknik Brainstorming selanjutnya siswa diberikan tes akhir (posttest) untuk mengukur serta melihat perbandingan keterampilan menulis karangan bahasa Jerman yang dicapai oleh siswa pada kelas eksperimen yang diajar dengan menggunakan teknik Brainstorming dan kelas kontrol yang diajar tanpa menggunakan teknik Brainstorming.

Tes yang diberikan adalah tes menulis karangan bahasa Jerman berdasarkan kata kunci yang diberikan kepada siswa. Kata kunci tersebut kemudian dikembangkan menjadi beberapa kalimat sehingga akan membentuk sebuah karangan bahasa Jerman.

Data yang diperoleh dianalisis dengan menggunakan analisis statistik inferensial untuk menguji hipotesis dengan menggunakan uji-t. Namun sebelum dilakukan pengujian hipotesis terlebih dahulu dilakukan uji normalitas dengan menggunakan tabel Z-score dan chikuadrat dan uji homogenitas dengan menggunakan uji F (Fisher), sebelum menentukan uji normalitas data dan homogenitas maupun uji hipotesis terlebih 
dahulu tentukan nilai rata-rata (mean), simpangan baku dan varian.

\section{PEMBAHASAN}

Pada bagian ini dibahas tentang hasil yang diperoleh dari analisis data penelitian tentang keefektifan teknik Brainstorming dalam keterampilan menulis karangan bahasa Jerman siswa kelas XI IPA SMA Negeri 1 Sungguminasa. Dalam penelitian ini, pembelajaran dilakukan selama tiga kali pertemuan setelah pemberian pre-test pada kelas XI IPA 2 sebagai kelas eksperimen dan XI IPA 1 sebagai kelas kontrol. Pada kelas eksperimen siswa diajar dengan menggunakan teknik Brainstorming sedangkan pada kelas kontrol siswa di ajar seperti biasanya yaitu dengan metode ceramah atau diskusi.

Hasil pre-test menunjukkan bahwa nilai rata-rata (mean) kelas XI IPA 2 sebagai kelas eksperimen dari 35 siswa sebesar 45,71, dengan hasil analisis meunjukkan bahwa 1 siswa memeroleh nilai tertinggi, yakni 71 sementara itu terdapat 11 siswa yang memeroleh nilai terendah, yakni 29. Rendahnya perolehan nilai siswa tersebut karena informasi yang disampaikan dalam tulisan tidak terlalu komunikatif dan dibeberapa bagian penulisan terdapat kesalahan, kalimat yang ditulis juga terdapat banyak kesalahan baik secara leksik, morfologi, sintaksis dan ortografis sehingga tidak dapat dimengerti.

Hasil pre-test rata-rata (mean) kelas XI IPA 1 sebagai kelas kontrol sebesar 50,61 dengan analisis menunjukkan bahwa 3 siswa memeroleh nilai tertinggi yakni 71 dan 3 siswa juga yang memeroleh nilai terendah, yakni 29 dalam keterampilan menulis karangan bahasa Jerman. Rendahnya perolehan nilai siswa tersebut karena informasi yang disampaikan dalam tulisan tidak terlalu komunikatif dan dibeberapa bagian penulisan terdapat kesalahan, serta kalimat yang ditulis juga terdapat banyak kesalahan baik secara leksik, morfologi, sintaksis dan ortografis sehingga tidak dapat dimengerti.

Nilai pre-test pada kedua kelas tersebut kemudian dilanjutkan dengan uji normalitas dan uji homogenitas data. Pada uji normalitas data pre-test menunjukkan bahwa kelas eksperimen dan kontrol memiliki chi-kuadrat hitung lebih kecil dari chi-kuadrat tabel, pada kelas eksperimen diperoleh $\mathrm{X}_{\text {hitung }}\left(-198,56<\mathrm{X}_{\text {tabel }}(11,07)\right.$ begitupun pada kelas kontrol, chi-kuadrat hitung lebih kecil dari chi-kuadrat tabel, yaitu $\mathrm{X}_{\text {hitung }}(-172,02)<\mathrm{X}_{\text {tabel }}(11,07)$. Jadi distribusi data pre-test pada kelas eksperimen dan kelas kontrol dinyatakan normal, artinya tes yang diberikan sesuai dengan kemampuan siswa. Adapun hasil uji homogenitas menunjukkan bahwa $F_{\text {hitung }}$ lebih kecil daripada $F_{\text {tabel. }} \quad(1,62<5,050)$. Hal ini berarti bahwa kelompok data pada kelas eksperimen dan kontrol dinyatakan homogen.

Pemberian pre-test kemudian dilanjutkan dengan pembelajaran yaitu pemberian perlakuan (treatment) pada kelas eksperimen, yakni penggunaan teknik Brainstorming sedangkan pada kelas kontrol pembelajaran berlangsung seperti biasa, yaitu secara konvensional berupa ceramah dan diskusi. Setelah pembelajaran yang berlangsung selama tiga kali pertemuan kedua kelas kemudian diberikan tes akhir (post-test).

Hasil post-test pada kelas eksperimen, yakni pembelajaran dengan menggunakan teknik Brainstorming mengalami peningkatan nilai yang cukup signifikan. 
Hal ini dapat dibuktikan dengan perolehan nilai rata-rata (mean) pada kelas eksperimen sebesar 68,57 yang sebelumnya hanya sebesar 45,71 dengan analisis menunjukkan bahwa 12 siswa memeroleh nilai tertinggi, yakni 86 dan hanya 2 siswa memeroleh nilai terendah, yakni 14. Siswa telah mampu menyampaikan informasi yang disampaikan dalam tulisan dengan sangat komunikatif sesuai dengan tema serta kalimat-kalimat yang ditulis hanya mengandung sedikit kesalahan leksik, morfologi, sintaksis, dan ortografis tetapi tidak mengganggu urutan sistematika penulisan dalam karangan bahasa Jerman tersebut.

Hasil post-tes pada kelas XI IPA 1 sebagai kelas kontrol tidak mengalami peningkatan nilai yang cukup signifikan. Hal ini dapat dibuktikan dengan perolehan nilai rata-rata (mean) pada kelas kontrol sebesar 51,02 yang sebelumnya sebesar juga sebesar 50,61 dengan hasil analisis menunjukkan bahwa hanya ada 4 siswa yang memeroleh nilai tertinggi, yakni 71 dan 4 siswa yang memeroleh nilai terendah, yakni 29. Rendahnya perolehan nilai siswa tersebut disebabkan karena informasi yang disampaikan dalam tulisan tidak terlalu komunikatif bahkan terdapat tulisan yang tidak dimengerti dan tidak sesuai dengan tema, serta kalimat yang ditulis terdapat banyak kalimat yang ditulis terdapat banyak kesalahan baik secara leksik, morfologi, sintaksis dan ortografis sehingga tidak dapat dimengerti.

Uraian di atas jelas menggambarkan bahwa pembelajaran menggunakan teknik Brainstorming lebih efektif dalam keterampilan menulis karangan bahasa Jerman. Hal ini dibuktikan berdasarkan hasil analisis uji hipotesis menggunakan rumus uji-t yang diperoleh yakni $t_{\text {hitung }}=\mathbf{5 , 4 7}$ sementara $t_{\text {tabel }}=\mathbf{1 , 9 9 8}$, jadi $t_{\text {hitung }}>t_{\text {tabel }}$ $(5,81>1,998)$. Dengan demikian, hipotesis yang menyatakan bahwa penggunaan teknik Brainstorming efektif dalam keterampilan menulis karangan bahasa Jerman siswa kelas XI IPA SMA Negeri 1 Sungguminasa dinyatakan diterima. Sehingga dapat disimpulkan bahwa penggunaan teknik Brainstorming efektif dalam keterampilan menulis karangan bahasa Jerman siswa kelas XI IPA SMA Negeri 1 Sungguminasa Kabupaten Gowa.

Temuan penelitian ini yang menyatakan teknik Brainstorming efektif dalam keterampilan menulis karangan bahasa Jerman didukung oleh teori yang dikemukakan oleh Sudiyono dkk (2006:120) bahwa Brainstorming adalah sebuah teknik yang digunakan dalam suatu pembelajaran untuk membantu siswa memikirkan sebanyak mungkin ide dan gagasan. Selama berlangsungnya curah pendapat, siswa didorong untuk menghasilkan pendapat atau gagasan secepat mungkin tanpa perlu memikirkan nilai dari pendapatnya itu.

\section{KESIMPULAN}

Teknik Brainstorming efektif dalam pembelajaran keterampilan menulis karangan bahasa Jerman siswa kelas XI IPA SMA Negeri 1 Sungguminasa Kabupaten Gowa. Keefektifan tersebut dapat dilihat dari hasil analisis uji-t pada nilai post-test siswa setelah dilakukan uji-t pada masingmasing kelompok dengan hasil analisis data yaitu $\mathrm{t}_{\text {hitung }}=5,81>\mathrm{t}_{\text {tabel }}=1,998$ pada taraf signifikansi 0,05.

Keterampilan menulis karangan bahasa Jerman siswa kelas XI IPA 2 SMA Negeri 1 Sungguminasa Kabupaten Gowa 
mengalami peningkatan yang signifikan setelah menerapkan teknik Brainstorming, siswa telah mampu untuk menulis sebuah karangan bahasa Jerman dengan baik, mampu mengembangkan setiap pokok pikiran menjadi sebuah karangan bahasa Jerman.

\section{DAFTAR PUSTAKA}

Abbas, Saleh. 2006. Pembelajaran Bahasa Indonesia yang Efektif di Sekolah Dasar. Jakarta: Departemen Pendidikan Nasional.

Akhadiah, Sabarti. 2003. Pembinaan Kemampuan Menulis Bahasa Indonesia. Jakarta: Erlangga.

Dalman. 2012. Keterampilan Menulis. Jakarta: PT Raja Grafindo Persada.

Iskandarwassid dan Dadang Sunendar. 2009. Strategi Pembelajaran Bahasa. Bandung: PT Remaja Rosdakarya.

Suprijanto. 2009. Pendidikan Orang Dewasa Dari Teori Hingga Aplikasi. Jakarta: PT Bumi Aksara.

Sudiyono, dkk. 2006. Strategi Pembelajaran Partisipatori Di Perguruan Tinggi. Malang: UINMalang Press.

Roestiyah. 2008. Strategi Belajar Mengajar. Jakarta: Rhineka Cipta.

Meisin. 2015. "Keefektifan Teknik Brainstorming Terhadap Pembelajaran Menulis Cerpen Pada Siswa Kelas XII SMA Bawakaraeng Makassar". Skripsi. Makassar : FBS UNM.

Nurmiati, N., \& Mantasiah, R. 2017. Keefektifan Penggunaan Metode Pembelajaran Tutor Sebaya (PeerTeaching) Dalam Kemampuan Membaca Memahami Bahasa Jerman Siswa Kelas XI IPA SMA Negeri 1 Bontonompo Kabupaten Gowa.
Eralingua: Jurnal Pendidikan Bahasa Asing dan Sastra, 1(1). 